\title{
A Scrutiny of Self Concept level of Bank customers as an Emerging Bank Marketing Strategy
}

\author{
T.S. Uma Rani, Easwaramoorthy Rangaswamy, Rtn. N. Panchanatham
}

\begin{abstract}
The study purpose is to focus with an analysis of Self Concept level of Bank customers as an Emerging Bank Marketing Strategy. The results of the present study shows that self-concept implicit as an essential factor for each and every individual and can transformones belief, attitude, and reaction towards their emerging marketing strategies and personal life. This study helps to comprehend the efficiency of the banks through their marketing strategies and the influence of self-concept variable of individual bank customers towards the meticulous bank. Thus, this paper concentrateson the relationship between the psychological variable self-concept levels of bank customers towards the specific commercial bank marketing strategies.
\end{abstract}

Index Terms: Self Concept level, marketing strategies, bank customers, behaviors, attitudes, and reactions.

\section{INTRODUCTION AND STUDY BACKGROUND}

The background of the study is based on the number of studies that have been conducted in various countries over a period of time. The current approaches to Internet behavioural marketing; has dealt with the parameters for bank selection. A comparative study of marketing strategies between public and private sector banks has been made and 7 P's (product, price, place, promotion, people, process and physical evidence - marketing mix) of marketing strategies has been evaluated ${ }^{[1]}$. The factors has identified the availability of technology-based services as the foremost cause for consumers to change the banks ${ }^{[2]}$. The customers' expectations and their level of satisfaction towards their banks quality of the services rendered were given importance ${ }^{[3]}$. The factors shaping Greek banks customer's perceptions of service quality and direct influence of perceptions on customer loyalty were dealt with ${ }^{[4]}$. The important choice criteria while choosing the right bank; is because of the various imagination of the individuals about the bank and this impact on their attitude, behavior and responses ${ }^{[5]}$. One of the important factors that progress this imagination is self-concept level ${ }^{[6]}$. This factor can broadly be well-defined as a several-dimensional concept that indicates one's perception of self in relative to any number of variables; such as teachers, gender characters and sex, ethnic identity, and many others ${ }^{[7]}$.An emphasize for bringing into line of consumers' self concept with their concept of the product, in

Revised Manuscript Received on July 05, 2019.

Dr. T.S. Uma Rani, Amity Global Institute, Singapore.

Dr. Easwaramoorthy Rangaswamy, Amity Global Institute, Singapore.

Dr.Rtn. N. Panchanatham, Department of Business Administration, Annamalai University, Chidambaram. India. the process of proficient purchase by an individual customer has been dealt with The companies have to plan in advance for suitable marketing mix strategy based on the self concept of a person ${ }^{[8]}$.

\section{STUDY OBJECTIVES}

The study was proposed with the following objectives:

- To explore the relationship that exist between the self concept level of the bank customers and bank marketing strategies

- To analyse the level of relationship that exists between the self concept level of the bank customers and bank marketing strategies

\section{HYPOTHESIS}

The hypotheses were formulated to explore the bond between the self concept level of the bank customers and bank marketing strategies

Hypothesis 1: There is a significant relationship between the self concept level of the bank customers and bank marketing strategies

Hypothesis 2: There exist a relationship between several independent variables of self concept level of bank customers and bank marketing strategies

\section{METHODOLOGY OF THE STUDY}

The study is to understand the performance of the banks through various bank marketing strategies and the influence of self-concept variables of individual bank customers towards it. It is descriptive study which includes both quantitative and qualitative data. A survey is conducted in the form of structured questionnaire. In total, 650 questionnaires were distributed in to the bank customers on convenient sampling. However, the valid response turned out to be 493 and the Responses were got from 11 commercial bank customers, out of which 7 Nationalized banks (SBI, Canara Bank, Indian Overseas Bank, Indian Bank, Bank of Baroda, Punjab National bank, Union Bank of India) and from 4 private bank (ICICI, HDFC, Axis Bank, Karur Vysya Bank).

The study was based on primary as well as secondary data. primary data was done by the questionnaire with direct, open-ended and closed-ended multiple choice questions containing demographic variables, bank marketing strategies and the psychological variable like self-concept level of the bank customers. The researcher has framed the

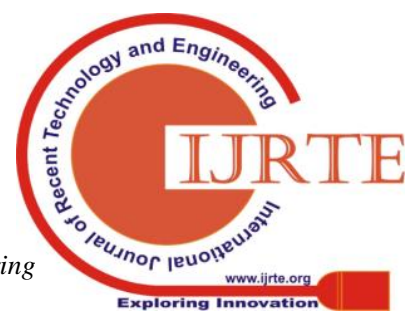


questionnaire on the basis of various reviews, personal interview with bank managers, marketing dimensions of 7 P's (marketing mix) and dimensions of service quality (SERVQUAL of Parasuraman, et al; 1998) in her study ${ }^{[9]}$. Secondary data were gathered from various sources such as university libraries, magazines, various books relating to marketing management, services marketing, online information, banking sources, past researches, reviews, etc; were used. The self-concept questionnaire is an inbuilt of Jennifer D. Campbell; Paul D. Trapnell; Steven J. Heine; Ilana M. Katz; Loraine E Lavallee; and Darrin, R.(1996), taken from Self-Concept Clarity: Measurement, Personality Correlates, and Cultural Boundaries from Journal of Personality and Social Psychology, This tool consists of four styles with 12 items.

\section{V.STUDY AIM}

To analyze the personal profiles and how the psychological variables of self-concept level of bank customers influences them towards the specific commercial banks. And to explore the impact of marketing strategies on private and nationalized banks and factors that influences the customers to select the particular bank.

\section{REVIEW OF LITERATURE}

There has been a significant amount of literature about customers' perception and marketing strategies adopted by the banks in various countries. Investigation done on the perceptions, attitudes and behavior of the adolescence market regarding online banking services. Data collection was done through a survey among 164 bank customers and found that the age group of 16-29 have a high level of positive attitudes and behavioral intentions to online banking services when compared to other age groups. It has also established that there is a high positive impact of customer satisfaction and loyalty towards online banking services. The study focused on a defined segment of UK university towards online banking services. The findings of the study helped the bank marketing services to have a clear picture about young users of online banking services and their advancement in the future ${ }^{[10]}$.

Based on the various factors on which the business customers select the specific banks are interest rate on deposits, Overdraft services, types of securities used for hypothecation, documentation procedure on loan has been analyzed. The study also suggested to consider the additional factors like customer's loyalty and stakeholder's behavioral intentions. The findings of the study have paved way for valuable recommendations and improved bank marketing strategies to gain competitive advantage ${ }^{[11]}$.

The study has determined that self-confidence is one of the key backgrounds for the customers behavior towards the choice of specific brand and for customization. The researcher suggests that the similarity between the self-concept image of the customers and the image of the brand as important variables for numerous outcomes such as product amendment and customer satisfaction ${ }^{[12]}$.

There are different ways to reflect about oneself. The most widely used is self-concept and usually states to the total of a multifaceted, planned, and energetic system of educated feelings, attitudes, and spirits of an individual. The selfconcept is upholding physical and mental wellness of a person

and influenced by factors such as education of parents, unceasing dissatisfaction, sadness, and inner self-critical consequence on the progress of one's self-concept. when self-concept is positive it leads advancement in performance and actions, exactly in understanding oneself ${ }^{[13]}$. In other words, the self-concept stipulates that each and every person are choosy in their perceptions of spurs. Self is not only the stimulus but also an important aspect of human consideration. Overall, self-concept assumed as a multidimensional constructs that having one general facet and numerous specific facets ${ }^{[14]}$. Review suggested that the experience of feeling is built on two variables: biological stimulus and mental understanding of that stimulus. When one is inexact of their emotive state, they perhaps will infer by observing others stimulus in the similar condition ${ }^{[15]}$. Self-concept has been analyzed on how the consumers sight and recognize themselves, and has found that a fascinating character in defining the behavior of a consumer, extending from the influence of ad communications, assessments of brand extensions, as well as insights of product salience ${ }^{[16]}$

\section{ANALYSIS \& INTERPRETATION}

Table 1. Correlation between the self concept level of the bank customers towards bank marketing strategies

To find the correlation between customers' perception towards bank marketing and the variables that influences the self concept level of the bank customers.

\begin{tabular}{|c|c|c|c|}
\hline Sl.No & Self concept statements & $\begin{array}{l}\text { Customers' perc } \\
\text { Bank Marketing }\end{array}$ & $\begin{array}{l}\text { towards } \\
\text { gies }\end{array}$ \\
\hline \multirow[t]{3}{*}{1} & \multirow{3}{*}{$\begin{array}{l}\text { My beliefs are often } \\
\text { conflict with one another }\end{array}$} & Correlation & -0.017 \\
\hline & & Significance level & 0.710 \\
\hline & & Total & 493 \\
\hline \multirow[t]{3}{*}{2} & \multirow{3}{*}{$\begin{array}{l}\text { I have different opinion on } \\
\text { each day about my self }\end{array}$} & Correlation & $0.527(*)$ \\
\hline & & Significance level & 0.041 \\
\hline & & Total & 493 \\
\hline \multirow[t]{3}{*}{3} & \multirow{3}{*}{$\begin{array}{l}\text { Wondering about what } \\
\text { kind person really I am }\end{array}$} & Correlation & 0.015 \\
\hline & & Significance level & 0.745 \\
\hline & & Total & 493 \\
\hline \multirow[t]{3}{*}{4} & \multirow{3}{*}{$\begin{array}{l}\text { Sometimes I feel that I am } \\
\text { not really the person I } \\
\text { appear to be }\end{array}$} & Correlation & -0.018 \\
\hline & & Significance level & 0.859 \\
\hline & & Total & 493 \\
\hline \multirow[t]{3}{*}{5} & \multirow{3}{*}{$\begin{array}{l}\text { If I think about my past I } \\
\text { am not sure what I was } \\
\text { really like }\end{array}$} & Correlation & $-0.778(*)$ \\
\hline & & Significance level & 0.019 \\
\hline & & Total & 493 \\
\hline \multirow[t]{3}{*}{6} & \multirow{3}{*}{$\begin{array}{l}\text { Seldom experience } \\
\text { conflict between different } \\
\text { aspects of my personality }\end{array}$} & Correlation & $-0.614(*)$ \\
\hline & & Significance level & 0.023 \\
\hline & & Total & 493 \\
\hline \multirow[t]{3}{*}{7} & \multirow{3}{*}{$\begin{array}{l}\text { Sometimes I feel other } \\
\text { people know better than I } \\
\text { know myself }\end{array}$} & Correlation & -0.008 \\
\hline & & Significance level & 0.865 \\
\hline & & Total & 493 \\
\hline \multirow[t]{3}{*}{8} & \multirow{3}{*}{$\begin{array}{l}\text { My beliefs about myself } \\
\text { change very frequently }\end{array}$} & Correlation & $0.655(*)$ \\
\hline & & Significance level & 0.025 \\
\hline & & Total & 493 \\
\hline \multirow[t]{3}{*}{9} & \multirow{3}{*}{$\begin{array}{l}\text { Description about my } \\
\text { personality may be diff } \\
\text { from one day to another }\end{array}$} & Correlation & 0.051 \\
\hline & & Significance level & 0.259 \\
\hline & & Total & 493 \\
\hline \multirow[t]{3}{*}{10} & \multirow{3}{*}{$\begin{array}{l}\text { Even if I wanted to tell I } \\
\text { don't think I could tell } \\
\text { someone what I am really } \\
\text { like }\end{array}$} & Correlation & -0.051 \\
\hline & & Significance level & 0.256 \\
\hline & & Total & 493 \\
\hline
\end{tabular}




\begin{tabular}{|c|c|c|c|}
\hline \multirow[t]{3}{*}{11} & \multirow{3}{*}{$\begin{array}{l}\text { In general I have a clear } \\
\text { sense of who I am and } \\
\text { what I am }\end{array}$} & Correlation & $0.690(*)$ \\
\hline & & Significance level & 0.046 \\
\hline & & Total & 493 \\
\hline \multirow[t]{3}{*}{12} & \multirow{3}{*}{$\begin{array}{l}\text { It is often hard for me to } \\
\text { make up my mind about } \\
\text { things because I don't } \\
\text { really know what I want }\end{array}$} & Correlation & 0.026 \\
\hline & & Significance level & 0.565 \\
\hline & & Total & 493 \\
\hline
\end{tabular}

Note: ** Correlation is significant at the 0.01 level (2-tailed)

*Correlation is significant at the 0.05 level (2-tailed).

From the above it is very clear that there exists a significant positive, moderate relationship that exist between the self concept statement namely 'I have different opinion on each day about myself '(0.527) and overall bank marketing strategies, which shows that there are customers, who change the opinion about themselves are easily influenced by the external force called bank marketing strategies; there exist a strong positive relationship between the statements 'My beliefs about myself change very frequently'(0.655) and 'In general I have a clear sense of who I am and what I am' (0.690) towards the overall bank marketing strategies. These relationships clearly explains that both type of person who change himself frequently and clear about what he is doing are influenced by the bank marketing strategies.

There exist a negative, but a strong significant relationship between the statements 'If I think about my past I am not sure what I was really like' $(-0.778)$ and Seldom experience conflict between different aspects of my personality (-0.614) towards bank marketing strategies, which shows that the customer's mind are not stable they change according to the external and internal stimulus. Thus, the customers' perception towards the bank marketing strategies differs on the basis of their self concept level.

Table 2. Level of relationship between bank marketing strategies and their customer's self concept level

To find the relationship between overall marketing strategies of the commercial banks and statements that influences the self concept level of the bank customers.

\begin{tabular}{|c|c|c|c|c|}
\hline $\begin{array}{l}\text { Sl. } \\
\text { No. }\end{array}$ & Self concept statements & $\begin{array}{l}\text { Unstandardized } \\
\text { Coefficient } \\
\text { (Beta) }\end{array}$ & t Value & $\begin{array}{l}\text { Significance } \\
\text { (p) }\end{array}$ \\
\hline & (Constant) & 2.484 & 14.684 & $0.000 * *$ \\
\hline 1 & $\begin{array}{l}\text { My beliefs about myself often } \\
\text { conflict with one another }\left(\mathrm{X}_{1}\right)\end{array}$ & -0.026 & -0.698 & 0.485 \\
\hline 2 & $\begin{array}{l}\text { I have different opinion on each day } \\
\text { about myself }\left(\mathrm{X}_{2}\right)\end{array}$ & 0.165 & 5.131 & $0.036 *$ \\
\hline 3 & $\begin{array}{l}\text { Wondering about what kind person } \\
\text { really I am }\left(\mathrm{X}_{3}\right)\end{array}$ & -0.025 & -0.693 & 0.489 \\
\hline 4 & $\begin{array}{l}\text { Sometimes I feel that I am not } \\
\text { really the person I appear to be }\left(\mathrm{X}_{4}\right)\end{array}$ & 0.044 & 1.219 & 0.224 \\
\hline 5 & $\begin{array}{l}\text { If I think about my past I am not } \\
\text { sure what I was really like }\left(\mathrm{X}_{5}\right)\end{array}$ & -0.023 & -4.626 & $0.032 *$ \\
\hline 6 & $\begin{array}{l}\text { Seldom experience conflict } \\
\text { between different aspects of my } \\
\text { personality }\left(\mathrm{X}_{6}\right)\end{array}$ & -0.041 & -3.160 & $0.047 *$ \\
\hline 7 & $\begin{array}{l}\text { Sometimes I feel other people know } \\
\text { better than I know myself }\left(\mathrm{X}_{7}\right)\end{array}$ & 0.012 & 0.353 & 0.724 \\
\hline 8 & $\begin{array}{l}\text { My beliefs about myself change } \\
\text { very frequently }\left(\mathrm{X}_{8}\right)\end{array}$ & 0.132 & 3.048 & $0.042 *$ \\
\hline 9 & $\begin{array}{l}\text { Description about my personality } \\
\text { may be diff from one day to } \\
\text { another }\left(X_{9}\right)\end{array}$ & -0.001 & -0.034 & 0.973 \\
\hline 10 & $\begin{array}{l}\text { Even if I wanted to feel I don't think } \\
\text { I could tell someone what I am } \\
\text { really like }\left(\mathrm{X}_{10}\right)\end{array}$ & -0.046 & -1.201 & 0.230 \\
\hline 11 & $\begin{array}{l}\text { In general I have a clear sense of } \\
\text { who I am }\left(X_{11}\right)\end{array}$ & 0.229 & 8.675 & $0.000 *$ \\
\hline 12 & $\begin{array}{l}\text { It is often hard for me to make up } \\
\text { my mind about things because I } \\
\text { don't really know what I want }\left(\mathrm{X}_{12}\right)\end{array}$ & 0.049 & 1.367 & 0.172 \\
\hline & $\mathrm{R}$ value & \multicolumn{3}{|l|}{0.219} \\
\hline & R square value & \multicolumn{3}{|l|}{0.048} \\
\hline & F value & \multicolumn{3}{|l|}{4.019} \\
\hline
\end{tabular}

The independent variables that have significant

Note: * Significant at the 0.05 level (2-tailed)

** Significant at the 0.01 level (2-tailed)

S- Significant NS- Not Significant relationships are "I have different opinion on each day about myself", " If I think about my past I am not sure what I was really like", "Seldom experience conflict between 
different aspects of my personality", "My beliefs about myself change very frequently" and "In general I have a clear sense of who I am".

$\mathrm{Y}=$ Here, the dependent variable is customers perception towards bank marketing strategies

$\mathrm{X}=$ Here, the independent variables are self concept level statements

$\mathrm{Y}^{\wedge}=2.484+(-0.026) \mathrm{X}_{1}+(0.165) \mathrm{X}_{2}+(-0.025) \mathrm{X}_{3}$ $+(0.044) \mathrm{X}_{4}+(-0.023) \mathrm{X}_{5}+(0.041) \mathrm{X}_{6}+(0.012) \mathrm{X}_{7}$

$+(0.132) \mathrm{X}_{8}+(-0.001) \mathrm{X}_{9}+(-0.046) \mathrm{X}_{10}+(0.229)$ $\mathrm{X}_{11}+(0.049) \mathrm{X}_{12}$

Where $\mathrm{Y}^{\wedge}$ is the estimated effectiveness of the customer perception towards bank marketing strategies on self concept level of the bank customers.

The above equation describes that overall opinion on customer perception towards bank marketing strategies increases by 0.165 unit for every one unit increase in the self concept level of bank customers with regard to "I have different opinion on each day about myself", (-) 0.025 unit for every one unit decrease with regard to "If I think about my past I am not sure what I was really like", (-) 0.041 unit for every one unit decrease with regard to "Seldom experience conflict between different aspects of my personality, 0.132 unit for every one unit increase with regard to "My beliefs about myself change very frequently" and 0.229 for every one unit increase with regard to "In general I have a clear sense of who I am". Also, it could be inferred that "In general I have a clear sense of who I am" is the best predictor of personality level towards their perception on bank marketing strategies among other predictors.

The R Square value has only $4.8 \%$, and shows the level of relationship with the overall self concept variables and the bank marketing strategies. The multiple $\mathrm{R}$ is 0.219 , which reveals that there exists a relationship of 21.9 percent between customer perception towards bank marketing strategies and different self concept levels of the bank customers. The $\mathrm{R}$ Square value of 0.048 confirmed that the variable explained 4.8 percent variation in the customers' perception towards bank marketing strategies. If the ' $p$ ' value is less than 0.01 or 0.05 , then the significant relationship exists between the independent variable and dependent variable. Thus, only certain self concept variables were found to have significant relationship with the customers' perception towards bank marketing strategies. It is understood that self concept level of the bank customers will influence the bank marketing strategies.

\section{FINDINGS \& CONCLUSION}

There exists a significant positive, moderate relationship exist between the self concept statement like 'I have different opinion on each day about myself, and overall bank marketing strategies, which shows that there are customers, who change the opinion about themselves are easily influenced by the external force called bank marketing strategies; there exist a strong positive relationship between the statements 'My beliefs about myself change very frequently' and 'In general I have a clear sense of who I am and what I am' towards the overall bank marketing strategies $^{[17]}$. These relationships clearly explains that both type of person who change himself frequently and clear about what he is doing are influenced by the bank marketing strategies. There exist a negative, but a strong significant relationship between the statements 'If I think about my past I am not sure what I was really like' and Seldom experience conflict between different aspects of my personality towards bank marketing strategies, which shows that the customer's mind are not stable they change according to the external and internal stimulus. Thus the customers' perception towards the bank marketing strategies differs on the basis of their self concept level.

Also, it could be inferred that "In general I have a clear sense of who I am" is the best predictor of personality level towards their perception on bank marketing strategies among other predictors. Thus it is proved that bankers need to concentrate the psychological variables in the new emerging markets. Here the self-concept level of the bank customers plays a vital role while selecting the specific banks by them which in turn influence the bankers to adopt many new marketing strategies according to this psychological variable for the introduction of new products and services.

\section{REFERENCES}

1. Lajuni, N., Wing, B. L., \& Ghazali, M. (2010), "Bank Selection Criteria Employed by Customers in Labuan: A Study" The IUP Journal of Bank Management, IX(1 \& 2), 102-109.

2. Sudha Dhawan (2009), "An insight into factors influencing bank selection decisions of Indian customers." Institute of Productivity \& management Luknow.

3. ManraiLalita A and manirai Ajay K (2007), "A Filed Study of Customers Switching Behaviour for Bank Services", Journal of Retailing and Consumer Services, Vol.14, pp.208-215.

4. Koutovalas K and Siomkos G J (2006), "An examination of Relationship Between Service quality Perceptions and Customer Loyalty in Public Private Greek Banks", International Journal of Financial Services Management, Vol.14, pp.208-271.

5. Devlin J. Gerrard P (2005), “A study of Customer Choice Criteria for multiple bank users." Journal of Retailing and Customer Services; Vol.12, pp.297-306.

6. Weiten, W., Dunn, D. S., \& Hammer, E. Y. (2014), "Psychology Applied to Modern Life: Adjustments in the 21st Century", Belmont, CA: Wadsworth

7. Bong, M., \& Clark, R.E. (1999), "Comparison between self-concept and self-efficacy in academic motivation research", Educational Psychologist, 34(3), 139-153.

8. Ekinci, Y. and Riley, M. (2003): "An investigation of self-concept actual and ideal self-congruence is compared in the context of service evaluation", Journal of Retailing and Consumer Services, 10(4):201-14.

9. Parasaraman, A; Valarie A. Zeittmal and Leonard, 1. Berry; (1998) “A Conceptual Model of Service Quality and Its Implications for Future Reserch," Journal of Marketing Volume 49, Page 41-50.

10. Vinh Sum Chau, liqing W.L.C Nagai (2010), "The youth market for internet banking services perceptions, attitude and behaviour", Journals of services marketing, volume 24 no 1.

11. Uma Rani T.S., Dr. N. Panchanatham,(2011) “ Most preferred Business Banking Product of HDFC Bank in Trichy City", Journal of Economics and Behavioural studies, Volume- 2, No. 4, (April 2011), pp 177-185 (ISSN 2220-6140)

12. Sirgy,M.J.(1982):Self concept in consumer behaviour: A critical revie, Journal of consumer research,9:287-300.

13. Yahaya, A., \& Ramli, J.(2009), "The relationship between self-concept and communication skills towards academic achievement among secondary school students in Johor Bahru", International Journal of Psychological Studies, 1(2), 25-34

14. Tan, J. B. Y. \& Yates, S. M.(2007), “A Rasch analysis of 
the academic self-concept questionnaire", International Education Journal, 8(2), 470-484.

15. Bracken, B. A. (1992), Examiner's manual for the multidimensional self-esteem scale. Austin, TX: Pro-Ed

16. Monga, A. B., \& John, D. R. (2007): "Cultural differences in brand extension evaluation: The influence of analytic versus holistic thinking," Journal of Consumer Research, 33: 529-536.

17. Aida Mehrad (2016), "Mini Literature Review of Self-Concept", Journal of Educational, Health and Community Psychology" Vol 5, No

18. Jennifer, D., Campbell, Paul, D., Trapnell Steven, J., Heine; Ilana M., Katz; Loraine, E.,Lavallee; \& Darrin, R. (1996). Self-Concept Clarity: Measurement, Personality Correlates, and Cultural Boundaries. Journal of Personality and Social Psychology, 70(1), 141-156 